HENRY JAMES, WINCHELSEA, RYE \& THACKERAY'S DENIS DUVAL By Philip Horne, University College London

My subject is a strange essay - the only one of James's I can think of which combines so thoroughly travel writing, literary criticism and autobiography. It seemed a fitting topic for a centenary conference, as it commemorates a writer (Thackeray) who died while still writing the novel named in its title; and because it is an exercise in memory, personal, literary and historical. It comes close to home for James in various respects - looking back to the time when he dreamed of becoming a writer, and to what may be his earliest association with Rye - and to his actual beginnings as a published novelist. Indeed, it comes to the very doorstep of his then recently acquired home at Lamb House.

'Winchelsea, Rye and Denis Duval was written by 1 September 1899, first published in Scribner's Magazine in January 1901, and reprinted, with little revision, in English Hours (1905). It pairs two places - the neighbouring small towns Rye and Winchelsea in Sussex - and, actually, two texts - Thackeray's last, unfinished historical novel Denis Duval of 1864 and, less prominently, 'some far-away foolish fiction' (292), an unidentified and James unusually says unidentifiable English novel, now forgotten, of James's youth. (Denis Duval is also, implicitly, paired with, in competition with, James's essay itself). ${ }^{1}$

It's been bizarrely neglected by critics, for the most part - with the honourable exception of two (both at this conference). Adrian Poole in 'Dying before the End', his 1996 essay on James and serialisation, has a suggestive note calling it James's 'eloquent essay on incompleteness' (152 n.19). And one critic writes about it more extensively: Susan Griffin, in her book The Historical Eye: The Texture of the Visual in Late James, discusses it very interestingly and stimulatingly in terms of 
'James's excursive visual explorations of his historical self' (152). My concerns here will be a little different.

James's engagement with Denis Duval and its incompleteness goes back to the start of his literary career - is a long-gestated subject for him, an established mystery. Despite Thackeray's death on Christmas Eve, 1863, and its incompleteness, the novel continued to enjoy serial publication in the Cornhill Magazine, which Thackeray had founded and edited, till June 1864. Its failure to achieve full form left James with an abiding sense of the precariousness of serialisation - as shown by his reference in the Preface to The American to 'the sad warning of Thackeray's Denis Duval and of Mrs Gaskell's Wives and Daughters (that of Stevenson's Weir of Hermiston was yet to come)' (FW 1053).

A letter to T. S. Perry of March 1864 - the month after James had published his own first story - offers an extravagant barrage of literary jokes - inspired, it seems, by the death of Thackeray in his attempt to finish Denis Duval. James is trying to finish or 'to rewrite that modern novel I spoke of to you' - almost certainly a short story; and not having finished it, imagines himself in heaven. The logic being that Thackeray died and so Denis Duval remains unfinished; while James's story is unfinished, and James has consequently died... He writes as if the publishers were putting pressure on him as they did on Balzac:

Newport, Friday, March 25th 1864.

Dear Sarge - Your second letter quite put me to the blush. (If you examine my paper with Willie's microscope you will see that it reflects a faint ruby tinge. $)^{2}$ I had been meaning to give some sort of civil answer to your first, from day to day, but my pen, ink and paper - yea, even my small stock of wits - were engaged in advance. The printer's devil was knocking at the door. You know a literary man can't call his time his own. I wonder that you 
have enough for letter writing. What I mean is that I had made up my mind to finish a certain task or die in the attempt. The task is unfinished: and I have embraced the alternative. This [is] a spiritual, supernatural message. I write with a pen snatched from my angel-wing. It is very pleasant up here but rather lonely, the only other inhabitants being Shakespeare, Goethe and Charles Lamb. There are no women. Thackeray was up for a few days but was turned out for calling me a snob because I walked arm-in-arm with Shakespeare. I am rather sorry, for I am dying to hear the end of Denis Duval: that is an earthly expression. Now I am immortal. Heigh-ho. (LL 23)

The author of The Book of Snobs will never now confide details of the end of Denis Duval to James - for whom, therefore, on his return to earth and life, it will remain unfinished business.

There is no space here to give a full account of Thackeray's fascinating novelfragment, of which John Sutherland in his authoritative Thackeray at Work remarks that 'The astonishing feature of Dwval is that there is nothing tired about it, it promises in fact a recovery in age of the powers of youth' (110). Let me just say that Denis Duval is the child of Huguenot refugees, French Protestants who settle on the South-East coast, in Winchelsea, in the mid- $18^{\text {th }}$ century, and get involved in the local world of smugglers and other (including Catholic) French refugees. Denis nearly becomes a smuggler but is saved by his own pluck and the local vicar. Various plans and comments of Thackeray's make it fairly clear that Denis, whom we see joining the navy, was to get captured, become an admiral, and marry his childhood sweetheart).

Rye and Winchelsea are the two hilltop 'Antient Towns' which supported the medieval Cinque Ports - they were ports till the great storm of 1287 which 
changed the coastline and marooned them a mile or so inland. The present Winchelsea offers a particular parallel to the unfinished Denis Duval, insofar as it was grandly planned by Edward I on a modern-looking grid system - James mentions Turin and New York - in 1281 (before the storm, incidentally), but never seems to have reached the projected scale. James's 'essay on incompleteness' suggests that the central church, to match the town, never reached its intended size, but now the town website tells us that "There has been much speculation about whether the church of St Thomas was ever finished, but it is now generally accepted that it was. ${ }^{3}$ Here's James.

While Winchelsea dreamed, at any rate, she worked, and the noble fragment of her great church, rising solid from the abortive symmetry of her great square, helps us to put our hand on her deep good faith. She built at least as she believed - she planned as she fondly imagined. The huge ivy-covered choir and transepts of St. Thomas of Canterbury - to whom the structure was addressed - represent to us a great intention. They are not so mighty, but they are almost as brave, as the wondrous fragment of Beauvais. (288)

(Denis Duval too is of course a 'wondrous fragment'.)

Walled and closed on their unfinished side, they form at present all the church, and, with its grand lines of arch and window, its beautiful Gothic tombs and general hugeness and height, the church - mercifully exempt as yet from restoration - is wonderful for the place. (288)

There's the 'wonderfully perched cottage' of 'a very celebrated lady who resorts to the place in the intervals of an exacting profession' (296) (Ellen Terry) - which gives a view of Rye, looking like a boat but actually since the $13^{\text {th }}$ century stranded some distance from the coast, 'high and dry' (288) like Winchelsea: 
The wide, ambiguous flat that stretches eastward from Winchelsea hill, and on the monotone of whose bosom, seen at sunset from a friendly eminence that stands nearer, Rye takes the form of a huge floating boat, its water-line sharp and its bulk defined from stem to stern - this dim expanse is the great Romney Marsh, no longer a marsh today. (300)

The essay gives less detail in the essay on Rye, which is mainly seen as thus from Winchelsea. James may be thinking of the extension Denis Duval lacks, and that would have completed it, when he writes of

the compact little pyramid of Rye, crowned with its big but stunted church... I sigh when I think, however, what it might have been if, perfectly placed as it is, the church tower - which in its more perverse moods only resembles a big central button, a knob on a pin-cushion - had had the grace of a few more feet of stature. (299-300)

This might stand for James and his lesser achievement, as he sees it or pretends to, lesser that is than Thackeray's - which he looks across to, as it were, in Winchelsea. There is less about James's new home town of Rye, where he had just bought Lamb House: but the essay's illustrators, Ernest Peixotto for Scribner's Magazine and then Joseph Pennell for English Hours, both illustrate Mermaid Street. And James touches on Lamb House itself, as he emphasises visual representation in the essay (according to James, it's an element Thackeray has mystifyingly neglected): Rye attracts schools of art:

At favoured seasons there appear within her precinct sundry slouch-hatted gentlemen who study her humble charms through a small telescope formed by their curved fingers and thumb, and who are not unliable to define 
themselves as French artists leading a train of English and American lady pupils. They distribute their disciples over the place, at selected points, where the master, going his round from hour to hour, reminds you of nothing so much as a busy chef with many saucepans on the stove and periodically lifting their covers for a sniff and a stir. There are ancient doorsteps that are fairly haunted, for their convenience of view, by the 'class', and where the fond proprietor, going and coming, has to pick his way among paraphernalia or to take flying leaps over genius and industry. $(293-4)$

James himself is this 'fond proprietor' - the essay brings us up to, but not beyond, his threshold.

I've mentioned the pairings that are constitutive for this essay - and pairing, antithesis, comparison, is also a topic for us here. I need to look back myself now to Ralf Norrmann's 1982 book The Insecure World of Henry James's Fiction, which I reviewed. Norrmann claimed to have found the figure in James's carpet: 'chiasmus'. The claim of his book, as the dust-jacket sums it up, is that

from chiasmus comes not only James's relativism but his dualistic extremism, his ambilateralism (resulting in ambiguity), the sterility of his world and all those other peculiarities that have mystified James's readers through the years. The rhetorical figure of chiasmus is the key to James's mind. Whoever understands chiasmus, understands James.

The OED, by the way, defines 'chiasmus' simply: 'A grammatical figure by which the order of words in one of two parallel clauses is inverted in the other'. (An alternative, older term, going back to Puttenham, is antimetabole, which the OED defines as 'A figure in which the same words or ideas are repeated in inverse 
order'.) Chiasmus comes from $c h i(\chi)$, the Greek letter X - because of the mirroring in its shape, the criss-cross structure. It's basically ABBA: an example:

Are we looking at chiasmus [A] for what it tells us about James [B], or at James $[B]$ for what he shows about chiasmus [A]? It's a form, then, of often quite loose symmetry: a structure of thought, an analytical tool, a generator of ironies. For Ralf Norrmann, as that quotation shows, chiasmus in James, a dominant feature of the late style, is a psychopathology, obsession, and unconscious compulsion, as we've seen. Correspondingly, Norrmann's wild overclaims didn't encourage others to become fellow-chiasticists. But there's no necessity to take it this way: it's certainly become instinctive in later James, but seems a conscious element of style - helpful for a writer constantly engaged in the wear and tear of discrimination, working through a succession of comparisons. A is seen in the light of $\mathrm{B}$; then $\mathrm{B}$ in the light of $\mathrm{A}$ : a pattern one can see clearly in the two-Book structure of The Golden Bowl. It can also suggest a plot of retaliation, or of reversal of agency, where $A$ does something to $B$, then $B$ does it back to A (A subject, B object; B subject, A object - as in 'The Jolly Corner', or James's Louvre nightmare in A Small Boy and Others). Or in Jamesian terms, the subject may turn out to be as much the observer as the person or thing observed.

The essay's first paragraph should demonstrate why chiasmus or antimetabole loomed for me as a concern.

I have recently had a literary adventure which, though not followed by the prostration that sometimes ensues on adventures, has nevertheless induced meditation. The adventure itself indeed was not astounding, and I mention it, to be frank, only in the interest of its sequel. It consisted merely, on taking up an old book [A] again for the sake of a certain desired and particular light $[B]$, of my having found that the light $[B]$ was in fact not there to shine, but was, on the contrary, directly projected upon the book [A] 
from the very subject itself as to which I had invoked assistance. The case, in short, to put it simply, was that Thackeray's charming fragment of 'Denis Duval' [C] proved to have much less than I had supposed to say about the two little old towns $[\mathrm{D}]$ with which the few chapters left to us are mainly concerned, but that the two little old towns [D], on the other hand, unexpectedly quickened reflection on 'Denis Duval' [C]. Reading over Thackeray [E] to help me further [F] to Winchelsea [G], I became conscious, of a sudden, that Winchelsea $[G]$ - which I already in a manner knew - was only helping me further $[\mathrm{F}]$ to Thackeray $[\mathrm{E}]$. Reinforced, in this service, by its little sister-city of Rye, it caused a whole question to open, and the question, in turn, added a savour to a sense already, by goodfortune, sharp. Winchelsea and Rye form together a very curious small corner $[\mathrm{H}]$, and the measure, candidly undertaken, of what the unfinished $[\mathrm{I}]$ book [] had done $[\mathrm{K}]$ with them, brought me to a nearer view of them - perhaps even to a more jealous one; as well as to some consideration of what books [] in general, even when finished [] , may do $[\mathrm{K}]$ with curious small corners $[\mathrm{H}]$. (275-6)

These chiasmi are essentially a set of four variations on the same reversal of agency. James reads Denis Duval to help him write about Winchelsea and Rye; he finds the reality of Winchelsea and Rye makes him think more about them and the book. The last sentence offers a highly wrought reversal - not quite a mirror: HIJKJIKH.

The pattern continues to play out - a theme and variations, one might say - of the opposition of book and place. 
Happy and enviable always the first trepidation of the artist who lights on a setting $[A]$ that 'meets' his subject $[B]$ or on a subject $[B]$ that meets his setting [A]. (280)

In some cases the logical structure continues without the actual verbal repetition, in abbreviated (here) or elegantly varied form:

The editorial notes to Denis Duval yield unfortunately no indication of whether Winchelsea [A] put into his head the idea of this study [B], or of whether he carried it [the idea of this study] [B] about till he happened judiciously to drop it there [in Winchelsea] [A]. (280)

Chiasmus becomes in fact a 'formula' to 'seize' - at the point in the essay where James is wondering why - as he alleges, anyhow - there is such a deficit of visual representation of Winchelsea and Rye in Denis Duval. This seems the more striking because Winchelsea and Rye are now thronged with those art-students:

Rye is in truth a rudimentary drawing-lesson, and you quite embrace the question when you have fairly seized the formula. Nothing so 'quaint' [A] was ever so easy $[B]$ - nothing so easy $[B]$ was ever so quaint $[A]$. (293)

James has certainly 'seized the formula' - Rye and Winchelsea in some places are a simple pairing ('curious small corners'), but in others are wittily contrasted:

The great thing is that if you live at Rye [A] you have Winchelsea [B] to show; whereas if you live at Winchelsea [B] you have nothing but Rye [A] (299) 
The whole essay ends, if one wanted to be ingenious, with a pseudo-chiasmus, or at any rate a pair of mirrorings - but the main point is that it makes a couple of continental comparisons, to sites that have attracted artists:

[T] he point to be made is that, comparing small things with great - which may always be done when the small things are amiable - if Rye [A] and its rock $[B]$ and its church $[C]$ are a miniature Mont $[B]$-Saint [C]-Michel $[A]$, so, when the summer deepens, the shadows fall, and the mounted shepherds and their dogs pass before you in the grassy desert, you find in the mild English 'marsh' a recall of the Roman Campagna. (300-1)

Thackeray's novel basn't according to James brought out this pictorial aspect of the area, something his essay has tried to do - aided first by Peixotto and then by Pennell, but mainly through the medium of his own eloquent prose. ${ }^{4}$

If something completed is finished, a closed book, by contrast an unfinished project leaves an opening, invites one to come in and play with open questions. Denis Duval, James says, gains power by never being finished:

If, moreover, it after a few months broke short off, that really gave it something as well as took something away. It might have been as true of works of art as of men and women, that if the gods loved them they died young. (276)

It's remembered as a living symbol of promise still in motion. And James makes it a parallel to the town where it's mainly set: the thirteenth-century town of Winchelsea: 
The haven on the hill-top - a bold and extraordinary conception - had hardly had time to get, as we should now say, 'started', before it began to see its days numbered. (288)

This may be punning on the 'numbers' of a running serial. At any rate plans unfulfilled stimulate the imagination: incompleteness leads to a kind of fruitful imaginative abstraction, in projections, blanks, outlines. Edward I planned a great town - now a very small one, really a village, whose little centre is hardly the downtown it seems to have been conceived as, a Sussex New York. James says of Edward that

His abstract avenues and cross-streets straggle away, through the summer twilight, into mere legend and mystery. (291)

It's paradoxically a history that has never been realised, and that therefore can't be remembered as such - but it can be sensed. James's sense of the past here - and he planned his never-to-be-finished novel The Sense of the Past in the autumn of 1899 just after writing this essay - has a visionary, or rather a sensory, or even extrasensory, vivacity. This, for instance, is another quite magical sentence:

The air is like that of a room through which something has been carried that you are aware of without having seen it. (299)

A scent of the past, then? Of course, not everything is incomplete in Winchelsea: some things are just finished, over, gone. James also calls his awareness 'my sense of an obliterated history' (295) - which may be as in the previous quotation an uncanny sense of something that has vanished without trace - or just, less mystically, the sense that something that has vanished without trace. This can make one reflect on the moment of this essay, in this place. The place, a backwater that 
was once a waterfront and a hub and a site of international conflict (subject to French raids and the threat of invasion). The moment, that of the Boer War and the Spanish-American War. Underlying the essay, then, which was written for US consumption in Scribner's, may be thoughts of Empires and their ultimate fates hence perhaps the fact that the essay ends with the Roman Campagna, a grassy ruin of an ancient empire, commemorated by the American painter Thomas Cole, portrayer of 'The Course of Empire', in a later painting in 1843, the year of James's birth. In the long run, James may be reflecting, British and American imperialisms, and whatever future they have, will ineluctably turn to ruins and incomplete schemes and ambitions, like literary and architectural ones.

James's essay contains a quite remarkable, indeed contentious, argumentative move in his treatment of Denis Duval. He claims that even after 250 pages, in addition to failing in specific visual evocation of its setting, it doesn't have a recognisable subject. He represents himself, in fact, as impatient, like the characters in his own 'The Figure in the Carpet', to know the key to the work, what Denis Duval is 'about'. He records his having read it three times - and the last reading has been baffling. From the start Denis reveals that his childhood love-object Agnes is there beside him in married bliss as he writes, and James comments on this reduction of suspense:

The way in which this affects us as undermining the 'love-interest' bears remarkably on the specific question of the subject of the book as the author would have expressed this subject to his own mind. We get, to the moment the work drops, not a glimpse of his central idea; nothing, if such had been his intention, was in fact ever more triumphantly concealed. (278)

There's no real evocation of Winchelsea as a place, James says - no set-piece description: 
Winchelsea is strange, individual, charming. What could he - yes - have been thinking of? We are wound up for saying that he has given his subject away, until we suddenly remember that, to this hour, we have never really made out what his subject was to have been. (285)

And a little later,

It is the most puzzling thing in the world, but there is no clue. There are indications, in respect to the book, from Thackeray's hand, memoranda on matters of detail, and there is in especial a highly curious letter to his publisher; yet the clue that his own mind must have held never shows the tip of its tail. (285-6)

'The tip of its tail' suggests a hunt: an image James then saddles up and rides away in pursuit of.

The production of a novel finds perhaps its nearest analogy in the ride across country; the competent novelist - that is, the novelist with the real seat - presses his subject, in spite of hedges and ditches, as hard as the keen fox-hunter presses the game that has been started for his day with the hounds. The fox is the novelist's idea, and when he rides straight he rides, regardless of danger, in whatever direction that animal takes. As we lay down 'Denis Duval', however, we feel not only that we are off the scent, but that we never really have been, with the author, on it. The fox has got quite away. For it carries us no further, surely, to say - as may possibly be objected - that the author's subject was to have been neither more or less than the adventures of his hero; inasmuch as, turn the thing as we will, these 'adventures' could at the best have constituted nothing more than its form. It 
is an affront to the memory of a great writer to pretend that they were to have been arbitrary and unselected, that there was nothing in his mind to determine them. The book was, obviously, to have been, as boys say, 'about' them. But what were they to have been about? Thackeray carried the mystery to his grave. (286)

Thackeray's selection of adventures does suggest a subject, we could think they're all to do with law and loyalty, with a French boy and the forces that threaten to alienate him from society and others - forces he overcomes, partly by luck, in the process becoming heroically English. Perhaps James's insistence on being baffled, and on denying the novel any clear focus, is a continuation of his longstanding critical dispute with the middlebrows, from before 'The Art of Fiction', about 'story' and what it is - which arose from W. D. Howells's imprudent claims, in 'Henry James, Jr.' (1882), that 'The art of fiction has, in fact, become a finer art in our day than it was with Dickens and Thackeray' and that James stands for 'a new school' which proposes 'a novel which is an analytic study rather than a story' (70-1).

I'll end with another mystery, a vivid but unplaceable evocation, a complex piece of writing in which travel, literary criticism and autobiography mingle - and ending in a familiar Jamesian phrase. In the middle of the essay James shifts to Rye for a view of Winchelsea - but not to Lamb House and its garden-room, as one might have expected, but a garden and a pavilion on the cliff-edge of town, with a clear view west across the Marsh to Winchelsea. (James needs 'kind permission' (292) to gain access, we learn, so it's not his own refuge.) He shifts also into the realm of the fantastical - the essay must have been written about the same time as 'The Great Good Place' - inventing or at least idealising a great good place of wishfulfilment, a removed scene of ideal writing - an enclosure which opens up (through another chiasmus) to reveal a further protected site within. 
even now you may see things as you stand on the edge of the cliff: best of all on the open, sunny terrace of a dear little old $[\mathrm{A}]$ garden $[\mathrm{B}]$ - a garden [B] brown-walled, red-walled, rose-covered on its other sides, divided by the width of a quiet street of grass-grown cobbles from the house of its master, and possessed of a little old [A] glass-fronted, panelled pavilion which I hold to be the special spot in the world where Thackeray might most fitly have figured out his story. There is not much room in the pavilion, but there is room for the hard-pressed table and the tilted chair - there is room for a novelist and his friends. (291-2)

The table is 'hard-pressed' because its user is; perhaps, as in James's letter to Perry of 1864, 'The printer's devil was knocking at the door' and 'You know a literary man can't call his time his own.' There's room for a 'tilted chair', just one, for the writer to lean back in, musingly; but, oddly, equally, 'room for a novelist and his friends': presumably this is because the 'friends' in question are his characters, imaginary people who don't need chairs.

The panels have a queer paint and a venerable slant; the small chimney-place is at your back; the south window is perfect, the privacy bright and open. (292)

One registers the paradox enabled by the cliff-edge here: it's not overlooked, so enjoys 'privacy', but overlooks the landscape, so is 'bright and open'. We might compare the pavilion to this passage itself, partly so 'bright and open', so inviting, but partly private, resistant to identification. Now the pavilion, as Susan Griffin notes, becomes a 'receptacle' like Maggie's metaphoric cupboard in The Golden Bowl, where she piles her images: this is a source of images also, in an extraordinary piling-up of memories, fancies and emotions: ${ }^{5}$ 
How can I tell what old - what young - visions of visions and memories of images come back to me under the influence of this quaint receptacle, into which, by kind permission, I occasionally peep, and still more under the charm of the air and the view that, as I just said, you may enjoy, close at hand, from the small terrace? How can I tell why I always keep remembering and losing there the particular passages of some far-away foolish fiction, absorbed in extreme youth, which haunt me, yet escape me, like the echo of an old premonition? I seem to myself to have lain on the grass somewhere, as a boy, poring over an English novel of the period, presumably quite bad - for they were pretty bad then too - and losing myself in the idea of just such another scene as this. But even could I rediscover the novel I wouldn't go back to it. It couldn't have been so good as this; for this - all concrete and doomed and minimised as it is - is the real thing. (292)

Topographically, this site of the 'little old south-garden', as it's called later, seems to have been on the south side of Watchbell Street, which runs along behind the houses to the south of the Lamb House garden, with Winchelsea to the 'extreme right' (294). James's amanuensis at the time, the Scot McAlpine, had rooms in an annexe of the Hope Anchor Hotel at the end of Watchbell Street (and on its north side); it may have had a separate garden across the way. Alternatively, there may be an explanation for 'doomed' in the fact that in 1900, the year after the essay, a tiny neo-Gothic Catholic church dedicated to St Walburga was built, on a site now occupied by the church of St Anthony of Padua, a location in the middle of the south side of Watchbell Street which fits the bill even better.

Wherever the pavilion was, and whatever its original, the spatial and temporal relations in this passage are dizzyingly complex: James can only have come to 
know the pavilion recently, but it becomes in the world of forty years earlier 'the special spot in the world where Thackeray might most fitly have figured out his story'. And that memory of the truncated serialisation - from a time when James was already twenty - is supplanted by an even earlier, hazier one, of the 'far-away foolish fiction, absorbed in extreme youth', brought back to him 'there' with a sense of déjà-vu by associations of some kind - like May Bartram's face near the start of 'The Beast in the Jungle' (1903), which affects Marcher as 'the sequel of something of which he had lost the beginning' (CS 497). James is fairly sure it's 'an English novel of the period, presumably quite bad', whose scene of reading is 'on the grass somewhere', most likely in America, not in this garden. We have resources James lacked for source-hunting -but the mystery of the 'far-away foolish fiction' can't be definitively dispelled. One suggestion made by my Victorianist colleague Charlotte Mitchell imagines amusingly, and plausibly, that

James had always thought the summer house came in [Denis Duval] and sat down to write the article with the expectation that he would find it, which is one reason for his crossness with what he doesn't find there. ${ }^{6}$

She suggests that the novel in question may be Harrison Ainsworth's Mervyn Clitheroe (1858):

Although Mervyn Clitheroe is bilge, it is the same type of novel as Denis Duval, and David Copperfield ..., and Rob Roy \&c. - autobiographical narrative about a boy, cruel schoolmaster, benevolent guardian, villain school friend, betrayed peasant girl, lost will, gypsies, historical colour, people with bees in their bonnets, \&c. It's easy to imagine James getting the two novels muddled up in his head. (Ibid.) 
Here is the description in Merryn Clitheroe of the old summer-house which figures as a site of concealment, rendez-vous and drama in the novel:

In the course of the afternoon I took an opportunity of examining the summer-house. It was a pretty octagonal structure, situated, as I have already mentioned, on the top of a small mount, and had large windows looking in every direction over the gardens. Internally, this pleasant little structure had a coved ceiling, moulded and painted with frescoes, and the spaces between the windows were decorated in a similar manner. Its sole furniture consisted of some half-dozen rustic chairs and a table; and the latter being covered with a piece of old tapestry which hung down nearly to the ground, immediately suggested a place of concealment to me. (Book 3 Ch 17, 346-7)

This has 'windows', 'paint', 'gardens' 'little', 'chairs' and 'table' in common with James's structure. I have myself found another possibility, a novel by an American, but nautical like Denis Duval, and, like it and James's essay, set on the South Coast of England - involving the words 'pavilion' and 'cliff. The novel is The Two Admirals (1842), by Fenimore Cooper: its pavilion is a site of intrigue and of overhearing like the one in Mervyn Clitheroe; moreover, Denis actually becomes an Admiral in Thackeray's fragment (27 n.; 'on the accession of King George IV', i. e. in 1820).

One of these paths, too, led to a rustic summer-house-a sort of small, rude pavilion, constructed, like the fences, of fragments of wrecks, and placed on a shelf of the cliff, at a dizzy elevation, but in perfect security. (II, Ch. XIV, 200) 
Neither possible source has a conclusive ring, however - the garden-pavilion is a familiar fictional topos, and James's memory may be a composite: until something more clinching turns up we will remain, like James himself, in slightly uncanny uncertainties, mysteries, doubts.

James's passage ends with a well-known Jamesian phrase: 'this - all concrete and doomed and minimised as it is - is the real thing.' This is complex, and teasing. The pavilion is 'real' in the sense of physical: which may sound literal, as the phrase usually isn't elsewhere; but here it's to be preferred to the unidentified bad novel, perhaps, because a pavilion and a garden not only promote a success in art, they constitute one - as human buildings and landscapes can be cultural artefacts. When you have 'the echo of an old premonition', we can also register, the 'echo' from after and the 'premonition' from before, you miss what comes in the middle, the real thing itself - just as James keeps losing the details of the half-remembered fiction.

Writing this essay no doubt in his Garden Room at Lamb House, James wants to put - to imprison - Thackeray in a Rye pavilion of his own, to write the novel as James would want it, a 'modern novel', perhaps, in the phrase James uses about his 1864 short story, with visual and topographical details of the kind he craves inspired by the clear view of Winchelsea the pavilion affords. He declares that

I should, in truth, have liked to lock up our novelist in our little pavilion of inspiration, the gazebo at Rye, not letting him out till he should quite have satisfied us. (296)

The conceit - of James in a rage of curiosity as a kidnapper-fan, on the model of Stephen King's Misery - recapitulates the pairings with which he has been playing throughout - reader and writer, himself and Thackeray, his essay and Denis Dwal, Rye and Winchelsea. 
Philip Horne (UCL)

WORKS BY HENRY JAMES

CS_Complete Stories 1898-1910. Ed. Denis Donoghue. New York: Library of America, 1996. Print.

EH_English Hours. With Ninety-two illustrations by Joseph Pennell. London: William Heinemann, 1905. Print.

$F W$ - Literary Criticism: French Writers, Other European Writers, The Prefaces to the New York Edition. Ed. Leon Edel \& Mark Wilson. New York: Library of America, 1984.

LL-Henry James: A Life in Letters. Ed. Philip Horne. London: Penguin Press, 1999. PC—The Princess Casamassima. New York: Macmillan, 1886 (1-volume edition).

\section{OTHER WORKS CITED}

Ainsworth, Harrison. Meryyn Clitheroe (London \& New York: George Routledge \& Sons, n.d. [1 $1^{\text {st }}$ pub. 1858]). Print.

Cooper, James Fenimore. The Two Admirals. Philadelphia: Lea and Blanchard, 1842. 2 vols. Print.

Gérin, Winifred. Anne Thackeray Ritchie: A Biography. Oxford: Oxford University Press, 1981.

Griffin, Susan M. The Historical Eye: The Texture of the Visual in Late James. Boston: Northeastern UP, 1991.

Howells, W. D. 'Henry James, Jr.' (1882). W.D. Howells as Critic. Ed. Edwin H. Cady. London: Routledge \& Kegan Paul, 1973. 59-72. 
Horne, Philip. 'Leaden Shoes' (review of Ralf Norrmann). Essays in Criticism 33:4 (Oct. 1983), 353-62. Print.

Mitchell, Charlotte. Private email, 26 July 2015.

Norrmann, Ralf. The Insecure World of Henry James's Fiction: Intensity and Ambiguity.

London and Basingstoke: Macmillan, 1982. Print.

Oxford English Dictionary. Print.

Poole, Adrian. 'Dying before the End: The Reader in The Portrait of a Lady'. The

Yearbook of English Studies, Vol. 26, Strategies of Reading: Dickens and after

Special Number (1996), 143-153. Print.

Sutherland, J[ohn].A. Thackeray at Work. London: The Athlone Press, 1974. Print.

Thackeray, William Makepeace. Denis Duval. London: Smith, Elder \& Co, 1892.

Pocket Edition. Print.

http://www.winchelsea.net/visiting/winchelsea history pt10.htm

$1 \quad$ I am grateful for help and encouragement towards this essay from many people, especially Oliver Herford and Charlotte Mitchell. James probably reread Denis Duval as a result of his friendship with Thackeray's daughter the novelist Anne Thackeray Ritchie, and certainly read the Biographical Introductions she wrote for the Works of William Makepeace Thackeray in 13 volumes, published by Smith, Elder 1894-98, where Denis Duval appeared in volume XII. In the essay James recommends 'the charming series of introductions lately prepared by Mrs. Richmond Ritchie for a new and, so far as possible, biographical edition of her father's works' (285).

2 William James had enrolled in Harvard Medical School earlier in the year. 3 http://www.winchelsea.net/visiting/winchelsea history pt10.htm

$4 \quad$ James's assertion that Denis Duval lacks pictorial vividness can seem perverse in the light of a passage like the following, where Denis recalls watching his wifeto-be Agnes's doomed father see her for the first and last time: 'I have the picture in my mind now. I see a winding road leading down to one of the gates of our town; the blue marsh-land, and yonder, across the marsh, Rye towers and gables; a great silver sea stretching beyond; and that dark man's figure stooping and looking at the child asleep.' (50)

$5 \quad$ See Griffin, op. cit., 161. James mentions a similar pavilion in a walled garden at Medley in Ch. XXII of The Princess Casamassima (1886): which contains 'a 
row of novels, out of date and out of print - novels that one couldn't have found any more, and that were only there' (287-8). There's a pavilion in the garden at Harsh in Ch. XV of The Tragic Muse (1890). In The Ambassadors (1903) there is a pavilion at Gloriani's garden party; later it's from one in the garden of the Cheval Blanc that Strether sees Chad and Mme. De Vionnet on the river.

$6 \quad$ Charlotte Mitchell, private email, 26 July 2015. 